\title{
Legal Education as a Strategy for Change in the Legal Profession
}

Mary Jane Mossman

Osgoode Hall Law School of York University, mjmossman@osgoode.yorku.ca

Source Publication:

International Journal of the Legal Profession. Volume 10, Number 2 (2003), p. 149

Follow this and additional works at: https://digitalcommons.osgoode.yorku.ca/scholarly_works

Part of the Legal Education Commons, and the Legal Profession Commons

(c) $($ ) $\Theta \Theta$

This work is licensed under a Creative Commons Attribution-Noncommercial-No Derivative Works 4.0 License.

\section{Recommended Citation}

Mossman, Mary Jane. "Legal Education as a Strategy for Change in the Legal Profession." International Journal of the Legal Profession 10.2 (2003): 149

This Article is brought to you for free and open access by the Faculty Scholarship at Osgoode Digital Commons. It has been accepted for inclusion in Articles \& Book Chapters by an authorized administrator of Osgoode Digital Commons. 


\title{
Legal education as a strategy for change in the legal profession
}

\author{
MARY JANE MOSSMAN \\ Osgoode Hall Law School, York University, Toronto, Canada
}

\section{Introduction}

But where, if not in school and workplace, is society built and changed? ${ }^{1}$

In The Real World of Technology, the renowned Canadian physicist Ursula Franklin described the idea of technology as practice, a way of organising work and people. In her view, technology is not "the sum of the artifacts, of the wheels and gears, of the rails and electronic transmitters" but rather a system: "technology involves organization, procedures, symbols, new words, equations, and, most of all, a mindset". For Franklin, many recent developments in technology represent profound and violent transformations in human society. Significantly, moreover, she suggested that nothing short of a global reformation of major social forces can provide security for the world and its citizens, a reformation which seems, according to her analysis, to need the expertise and imagination of the legal profession:

Such a development will require the redefinition of rights and responsibilities, and the setting of limits to power and control. There have to be completely different criteria for what is permissible and what is not. Central to any new order that can shape and direct technology and human destiny will be a renewed emphasis on the concept of justice. The viability of technology, like democracy, depends in the end on the 
practice of justice and on the enforcement of limits to power. ${ }^{2}$

In the context of our general reassessment of legal education and the legal profession, Franklin's emphasis on the practice of justice offers an important challenge. To what extent can legal education resist the demands of the market which have so captured the ethos of legal practice, if not all of those who are legal practitioners? To what extent do legal educators have tools and strategies, as well as ideas, to challenge dominant ideologies of corporate (legal) agendas? Do law teachers have a responsibility to join (or lead?) voices that resist defining the world in terms of market pressures and the demands of globalisation?

Franklin's ideas provide the context for some reflections in this paper about gender equality in the legal profession. The paper is part of a larger project, examining both historical and contemporary contexts for women lawyers, which seeks to map the intersection between the entry of women to the legal profession and related developments in social equality movements and in the 'formation' of professional culture in law. It is also a work-in-progress about the relationships between legal education and the culture of the legal profession. The paper begins with a brief overview of recent literature about women in law, and then focuses on the recommendations of the task force established by the Canadian Bar Association to promote greater gender equality in the law and the legal profession in Canada in 1993. ${ }^{3}$ One recommendation suggested that law firms should engage in seminars about issues of gender equality, and as a result, I was requested to design and implement a series of seminars for three of the largest law firms in Toronto over a period of 4 years in the late 1990s. In earlier writing, ${ }^{4}$ I have focused on the special pedagogical challenges involved in such educational programming, and the need for problem-solving approaches quite different from traditional forms of continuing education for lawyers.

In this paper, I examine some perspectives on lawyering which seem important to an assessment of the role of education in fostering greater equality in the legal 
profession. In this context, Ursula Franklin's insights about the impact of technology offer ways of thinking about these challenges in terms of goals of building and changing society; as her perceptive question asks: "where, if not in school and workplace, is society built and changed?"

\section{Studies on women in law: problems and possibilities}

Women have been becoming lawyers in Canada for more than a century, ${ }^{5}$ yet, until relatively recently, women have represented only a tiny minority of lawyers and an even smaller number within the judiciary. ${ }^{6}$ Statistics assembled by the CBA task force indicated that the percentage of women members of the legal profession increased dramatically in all parts of Canada after 1970. By 1993, the task force report stated that women lawyers comprised $27 \%$ of the practising profession, although only $12 \%$ of federally-appointed judges; the report also concluded that women were generally under-represented in private practice and over-represented among those employed in government. ${ }^{7}$ This general pattern of increasing numbers of women members of the legal profession and the judiciary in Canada appears to be similar to trends in other Western jurisdictions. As a result, there has been a noticeable increase in scholarly attention to women's entry to the legal profession, both monitoring the rate of this changing demography and attempting to assess its potential to change the profession's traditional (male) culture. For example, in her comparative essay about women lawyers in several different countries around the world, Carrie Menkel-Meadow confirmed the trend of increasing numbers of women lawyers almost everywhere in the world. However, she also posed a question about the meaning of increased numbers of women lawyers, suggesting that whether women will be changed by the legal profession, or whether the legal profession will be changed by the increased presence of women is a different—and more importantquestion. ${ }^{8}$

In the 1990s, legal scholars in a number of jurisdictions have examined the experiences of women as lawyers and tried to assess their impact on law and the 
legal profession. For example, Clare McGlynn's 1998 study of women members of the legal profession in the United Kingdom documented the barriers and opportunities which continue to exist, as well as women's perseverance and optimism in personal stories of their experiences in academe, and as solicitors, barristers and judges..$^{9}$ McGlynn also argued that it is necessary to connect the concerns and struggles of these individual women lawyers to broader, institutional arrangements: "the economic structure of the firm and the legal profession, the nature of the law and legal culture, [and ...] the fact that women as a whole are disadvantaged in society as well as in the legal academy and profession". ${ }^{10}$

In another British study, Hilary Sommerlad and Peter Sanderson explored the experiences of women solicitors and the institutional and cultural barriers to their participation in the legal profession. ${ }^{11}$ Similarly, Mona Harrington's 1993 study of women lawyers in the United States provided an analysis of structural factors constraining women lawyers' roles, and examples from the lives of women lawyers illustrating the complexity of their individual choices within these constraints. ${ }^{12}$ Harrington identified barriers in the nature of law, legal education, and the culture of legal practice and law firms. She also suggested that media presentations of women lawyers too often ignore real problems; as a result, for women lawyers who perceive systemic double standards and discrimination, the problem is "to find a way to speak about them when the norms say that good women lawyers, successful women lawyers, see no such problems". ${ }^{13}$

Harrington's conclusions in the USA are, on the whole, more optimistic than Margaret Thornton's study of women lawyers in Australia-where she characterised women lawyers as "fringe-dwellers of the jurisprudential community". ${ }^{14}$ For Thornton, the reality of legal work at the present time constitutes a formidable barrier to changes which would effect gender equality goals; as she concluded, "neither an increase in the number of women nor the passing of time can provide an automatic remedy". ${ }^{15}$ In such a context, she suggested that women who "make 
it in a man's world" can do so only by assimilating the traditional (male) characteristics of the profession. In terms of effecting goals of gender equality, "there is nothing potentially radical about such women because they do not wish to change any aspect of legal practice as it is ..."; ${ }^{16}$ moreover, according to Thornton, conformity on the part of some women lawyers to the traditional culture of the profession confirms for many that gender is not an issue, a conclusion which absolves the profession from taking any initiatives that might further gender equality goals.

Although Thornton's analysis is pessimistic, it is supported by the conclusions of other scholars. For example, the 1995 study by Bernard Lentz and David Laband in the USA provided an assessment of thousands of responses to the National Survey of Career Satisfaction/Dissatisfaction administered by the American Bar Association in 1984 and again in $1990 .{ }^{17}$ Using pay and promotion criteria, the authors concluded that there was little overt discrimination against women lawyers in the United States, a finding which they acknowledged to be different from the conclusions of some other studies. However, they also asserted that differences in rates of pay or promotion would be "relatively easy to prove in a court of law", thus making these forms of discrimination risky. ${ }^{18}$ Instead, Lentz and Laband argued that forms of discriminatory behaviour against women lawyers were much more subtle and covert, making them harder to identify and challenge:

Relative to comparable men lawyers, women lawyers report a sense of powerlessness in the workplace, and they do not believe that their performance is evaluated on the basis of merit.... [Female] lawyers apparently experience subtle discrimination on margins that are not easily provable in a court of law.... Given that those women who are most knowledgeable about their rights suffer multidimensional discrimination, the effectiveness of existing civil rights law is called into question. ${ }^{19}$ 
In her recent study of relatively new entrants to the legal profession in the Canadian province of British Columbia, Joan Brockman also identified additional pressures as well as special limitations on career advancement for women lawyers, by contrast with their male colleagues. ${ }^{20}$ Although Brockman reported that men and women were initially drawn to the legal profession for quite similar reasons, her research revealed that they often experienced differing, gendered opportunities as members of the profession. Her interviewees provided data about differences in terms of 'fitting in' the profession, their experiences of discrimination and sexual harassment, and challenges of balancing work and family life. There was also some evidence that women were more reluctant to embrace the adversarial nature of legal work with as much ease as men who were lawyers. Her study is also important because it specifically focused on newly-admitted lawyers; clearly if this group of lawyers is continuing to experience gendered differences in the practice of law, then it is not 'just a matter of time' before the situation will inevitably change for the better. As Brockman reported:

Discrimination in the legal profession can come from a variety of sources... . [Some] men will discriminate against women simply because they are women. Although there was no measure of this in this study, the proportion of men who fell into this category seems to be small. Most of them are identified as belonging to the 'old boys'club', and are thought to be becoming relics of the past. However, according to some respondents, 'baby dinosaurs' are growing up to replace them. Some women in this study sacrificed their personal lives and sold their souls to their law firms in order to become partners. They were being let go with glowing recommendations, rather than being invited into partnerships. The men who were poised for partnership, on the other hand, saw little standing in their way. It is difficult to conclude that the legal profession has rid itself of discrimination. ${ }^{21}$ 
Brockman's study is also important because it takes account of links between gender equality in the legal profession and in the broader society, and because it recognises how personal 'choices' on the part of women lawyers must be understood within a social context. ${ }^{22}$ In this way, Brockman's study focuses on systemic, structural barriers which constrain opportunities for women lawyers more than for men who are lawyers-and on the resulting need for structural changes to overcome them. These conclusions in the Canadian context are similar to those of Sommerlad and Sanderson in the United Kingdom $;{ }^{23}$ as they argued, a strategy which supports women members of the legal profession must be 'multi-pronged', including measures to foster childcare provision, initiatives to bring more women into public bodies, and codes of practice (with procedures for monitoring and enforcing them) for public employees and also for firms which contract with the State..$^{24}$

All of these studies about women members of the legal profession recognised, at least to some extent, the broader context of changes within the profession, some of which continue to exacerbate women's opportunities as lawyers. Yet, to some extent, the emerging literature about critical changes in the nature and processes of legal work $^{25}$ has tended to exist in isolation from much of this literature about women lawyers (and other recent entrants to the profession): a kind of 'two solitudes' in critical legal scholarship. One exception to this approach is the longitudinal study of some Toronto law firms undertaken by sociologists John Hagan and Fiona Kay in the early 1990s to examine the impact of gender in survey data about the experiences of men and women lawyers in relation to: initial articling placements, progression to partnership, work and family conflicts, billing practices, and satisfaction levels. ${ }^{26}$ They concluded that the profession of law had become "a contested domain" by the end of the 1980s, with increased opportunities at the entry-level for both male and female lawyers but a shrinking proportion of partnership opportunities: a "glass ceiling" which "becamean increasing reality for women butalso for men": 
in large firms during the 1970s and 1980s... [The growth rate of lawyers accelerated in private firms, government and business, but it also] involved, in relative terms, a shrinking pool of centralized and concentrated partnerships in large firms, with increasing numbers of lawyers in intermediate and lower positions. In short, this was a period of growth with a ceiling on upward outcomes.... Although the actual numbers of women and men lawyers at partnership levels of these firms increased in absolute terms during this period, their relative shares of partnership positions declined, and this ceiling effect was more pronounced for women than for men. During this period, men and women were developing careers in a legal profession whose parameters were changing in ways that traditional conceptions of professional autonomy would not predict. ${ }^{27}$

Hagan and Kay's study offers a careful analysis of competing explanations for the differing experiences of men and women who are lawyers. In particular, they examined the explanation that gendered experiences among lawyers occur primarily as a result of different choices being made by men and women about their careers in the legal profession. According to this explanation, women lawyers who experience a relative lack of career progress have made 'choices' to invest less in their careers than in their families, by contrast with male lawyers. ${ }^{28}$ Significantly, this explanation for the different experiences of men and women lawyers assigns responsibility for choices to individual lawyers-if women lawyers wish to succeed, it is simply a matter of them behaving more like men in the legal profession. According to this theory, women lawyers bear individual responsibility for improving their career options; there is no need for the profession itself to change. Thus, in relation to Menkel-Meadow's question in her comparative study, the 'different choices' theory suggests that the answer is that the profession will change (some) women, but that the entry of women will not change the profession. ${ }^{29}$ 
Yet, according to the study conducted by Hagan and Kay, even when women invested in their careers to the same extent as men, women lawyers were not rewarded at levels comparable to male lawyers; thus, explanations for women lawyers' relative disadvantage in the profession based on 'different choices' were rendered unpersuasive. ${ }^{30}$ Instead, they argued that gender stratification theory, an explanation focusing on the structural constraints of law practice and legal culture, and the extent to which they impose constraints on women lawyers' choices, was more persuasive. Their focus on a more structural approach shifts attention "away from employees in order to focus on employers who are the source of many of their problems". ${ }^{31}$ Using this approach, Hagan and Kay recommended the adoption of broadly-based initiatives, including systematic tracking of firms' partnership decisions; tax incentives and other governmental policies to create more workplace flexibility; support from professional associations in designing ways to minimise work/family conflicts; education and prevention programmes; and the development of innovative model policies by law societies. ${ }^{32}$ As is evident, these recommendations do not focus primarily on the 'choices' of individual lawyers, but rather on systemic change in the practices of law firms and other legal institutions. Adopting this theory leads to a different response to Menkel Meadow's question: pursuant to the theory of gender stratification, it will be necessary for the profession to change as a result of the entry of women..$^{33}$

Yet, although Hagan and Kay, like other scholars of the legal profession, have suggested a need for change in the legal profession, it is less clear exactly how these necessary changes will occur. Particularly if appropriate changes depend on the intervention of firm managers, law societies, or other professional associations, it will be necessary to convince them of the long term benefits of gender equality initiatives, including employer self-interest in retaining women lawyers. ${ }^{34}$ Significantly, Hagan and Kay recommended education programmes for firms and other legal employers about the nature and consequences of gender inequality for the profession, a recommendation also included in the 1993 
report ${ }^{35}$ of the CBA task force-and the catalyst for my seminars for Toronto law firms in the late 1990s.

\section{Educating the profession: Touchstones for Change}

The CBA task force recognised that its report was being presented in a context of significant change in the structure and organisation of legal work in Canada, and elsewhere.$^{36}$ Indeed, one of the most interesting features of the report is its characterisation of the challenge of gender equality in the legal profession as an integral part of the re-shaping of the profession. For example, in the introductory comments of the task force chair, former Justice Bertha Wilson of the Supreme Court of Canada, the problem was presented as a problem about identity for members of the legal profession in relation to these new developments:

[The entry of women to the legal profession] 'shook up' the profession and men as well as women were forced to confront issues to which they had never given really serious thought before.... Lawyers realized that this was a time for moral and intellectual stock-taking, for taking a cold dispassionate look at where their profession was going. How was their profession faring in the larger context of society? Was it a profession they were proud to belong to? Or had it become a little tarnished over the years? Had it, as some suggested, become 'too commercialized'? Were people now in it for the money? Were we still the moral and intellectual leaders in our communities or were we just high-priced technicians at the beck and call of the corporate elite? In sum, did the profession still warrant the description 'noble and learned'?37

Although phrased rhetorically, Justice Wilson's questions clearly characterised goals of gender equality as part of an overall professional commitment to justice; ${ }^{38}$ for her, lawyers have independent responsibilities to promote justice, not merely their (corporate) clients' interests. Although not everyone would agree with this 
characterisation of the challenge, there can be no doubt or ambiguity about the nature of the professional values adopted by the CBA report. For Justice Wilson and the task force, ideas about justice were fundamental to concepts of lawyering. In the face of often overwhelming and competing pressures on lawyers to meet demands of global corporatism, such a stance may appear misguided, naive, even hopeless. Yet, since it was these underlying principles in the task force report which resulted in the gender equality seminars for Toronto law firms, the seminar experiment provides an interesting opportunity to examine this educational initiative in the context of legal practice demands. Equally significantly, it may be important to assess the extent to which the task force report can be characterised as an important 'voice of resistance' within the legal profession, and/or the extent to which it offers ideas and strategies critical to values and goals of legal education.

The Touchstones report systematically examined current policies and practices affecting women lawyers in private law firms and also in government, academe, administrative tribunals and the judiciary, ${ }^{39}$ and made a long list of recommendations (some quite controversial) which were subsequently considered in public discussions by the National Council of the Canadian Bar Association. ${ }^{40}$ Touchstones suggested that any transformation of the profession ${ }^{41}$ would require change at a number of different levels: "behaviours, attitudes, institutional policies and practices, and in the structure of the profession itself". ${ }^{42}$ Accordingly, the report concluded that the process of change would require the profession to question the way that law is practised as well as the profession's assumptions underlying the status quo. ${ }^{43}$ And significantly, the report identified "education about the nature of gender inequality in the legal profession [as] crucial":

What is needed for the legal profession is 'remedial human rights jurisprudence' accessible to non-specialists.... These messages should be repeated until they form the basis of a common understanding of our legal duties to our colleagues in the profession and beyond. ... We must 
develop a culture of 'problem-solving' for our own profession. Lawyers are trained to criticize and demolish arguments. In order to achieve gender equality, we must learn how to find creative solutions for our own internal problems. ${ }^{44}$

The emphasis on education in the Touchstones report, as a strategy for accomplishing institutional change in the legal profession in relation to gender equality goals, is interesting for a number of reasons. First, the emphasis on education suggests that current problems of gender inequality in the profession are mainly the result of a lack of knowledge; as a result, Touchstones assumes that the provision of knowledge through education will engender appropriate changes. In this way, education about gender equality becomes a means to an end, a process that is somehow separate from issues of power, economic resources, or human will within the profession. Second, the emphasis on education appears to assume that it is possible to provide information about the jurisprudence on gender equality which will per se engender new and different practices within the profession, as if education about gender equality were no different from information about new legislative amendments which must be incorporated into legal practice. This approach tends to underestimate the power of entrenched ideas about gender roles in the profession, and in the larger society. ${ }^{45}$ As well, the report's emphasis on education to remedy gender inequality overlooks the extent to which these challenges within the profession may require fundamental restructuring of institutions, as well as profound changes in individual attitudes and behaviours. At the very least, achieving such goals requires highly specialised education.

In spite of these potential limitations, however, several Toronto firms responded to the Touchstones recommendations and took up the challenge of providing education seminars about gender equality for several years after $1993 .{ }^{46}$ Although all of the firms had well-established programmes for continuing legal education, they 
approached the arrangements for offering these seminars with special care. All of the firms had conducted some internal surveys of their members' experiences on a variety of issues related to gender equality, so that the firms were able to identify some issues of special concern to be addressed by the programme. All the same, the creation of an appropriate seminar required a good deal of energy and creative pedagogy in the context of highly sophisticated and articulate members of the profession-many of whom had never (or hardly ever) analysed these issues before. ${ }^{47}$ In assessing the seminars, and the role of education generally as a strategy for change, a number of constraints can be identified. For example, a one-time-only seminar of two-and-a-half hours is unlikely to accomplish more than an introduction to the issues and problems, especially in the context of education about gender equality, where ideas may challenge longstanding attitudes, traditional and wellestablished practices, and stereotypical views about gender roles. Indeed, gender equality programmes which go beyond providing just information to challenge fundamental values, attitudes and behaviour require time for reflection and further discussion, a commodity all too rare in the environment of most large law firms. As I conducted these (perhaps somewhat unique) educational programmes for law firms over a number of years, the reality of workplace demands for lawyers in these firms meant that gender equality education frequently had to be 'fitted into' other, more important, pressures on them.

Moreover, it became clear that solutions to problems of gender inequality in legal practice could be addressed only if they did not challenge the priority accorded to work demands, or if they could be easily accommodated within the prevailing law firm culture. Thus, to the extent that the literature suggests that gender equality goals may require major changes to practices and cultures, they are unlikely to be adopted readily in law firms. Such a conclusion limits the usefulness of educational programmes to the provision of some basic conceptions of gender inequality issues; they appear to be much less useful as strategies for accomplishing substantive change in the legal profession. 


\section{Lawyers' work and 'asynchronicity': (re)defining justice and gender equality}

As Margaret Thornton suggested in her analysis of lawyers' work in Australia, strategies for accomplishing change in the legal profession must confront the nature of legal work and the culture within which legal work is done. Thornton's study is important for its sustained focus on the reality of legal work and the day-to-day culture of the profession in the 1990s. She also identified how both the nature of legal work and law firms' expectations have been changing in recent decades, exactly the same period in which women have begun to enter the legal profession in significant numbers:

... [W]hile acceptance of women within legal practice is hailed as a sign of progress, the dramatic changes that have occurred simultaneously in the structuring of law firms have rendered the advances a pyrrhic victory. The lawyer in the modern corporate law firm is subject to disciplinary practices that are a far cry from the claimed independence and autonomy of the past. The filling in of time sheets and the need to generate specific levels of income signify the most notorious manifestations of control.... The focus on income generation, effected through the phenomenon of billable hours, engenders a great deal of ambivalence among women, as employed solicitors are expected to dedicate themselves totally to their careers and to the firm.... Loyalty to the firm includes never complaining about its practices to an outside body 48

Thornton identified these changes in terms of the increasing 'corporatism' of law practice and the 'commodification' of lawyers, and revealed these developments as controlling factors in shaping the nature of practice and the culture of the modern legal profession. Similarly, Maureen Cain and Christine Harrington argued that "lawyers' work shapes as well as reinforces the power relations in society" and legal work most often 'translates' the needs of capital into legal rights. ${ }^{49}$ In such a context, 
as Thornton argued, law firm 'corporatism' both undermines equality goals and renders gender invisible..$^{50}$

These insights about legal practice are important in the context of Ursula Franklin's analysis of 'new' technologies and their 'asynchronicity'. She defined this term as the opposite of 'synchonicity':

... [While] synchronicity evokes the presence of sequences and patterns, fixed intervals or periodicities, coordination and synchronization, asynchronicity indicates the decoupling of activities from their functional time or space patterns.... The current widespread use of computer networks ... has led to ... the prevalence of asynchronicity, indicated by the loosening, if not the abandonment, of previously compulsory time and space patterns. This is a most significant change. No longer is one pattern superseded by another pattern; the change now appears as a move from an existing pattern to no discernable structure. I consider the evolving destructuring by asynchronicity as an extremely important, if not the crucial facet of the new electronic technologies. ${ }^{51}$

For Franklin, the role of asynchronicity in "unravelling social and political patterns" is troubling. As she explained, the development of the 'bitsphere' (the world of technological mechanisms) and its impact on the 'biosphere' (the organic and human world) has created fundamental changes and challenges for the world as we know it. For the purposes of this paper, moreover, Ursula Franklin's concept of asynchronicity 'coincides' in significant ways with Margaret Thornton's ideas about 'technocentrism' in the work and legal education oflawyers. Indeed, Thornton's list of features of lawyers' work is remarkably similar to the factors identified by Franklin as elements of 'asynchronicity':

$\Omega$ legal rules assume neutral rationality, thereby disqualifying all other knowledge;

$\Omega$ legal work requires acceptance of the normativity of existing practices; there 
is no encouragement to challenge existing practices or to see things in new ways;

$\Omega$ paid work is seen as the major focus of human activity and good lawyers are those who work the longest hours;

$\Omega$ adoption of billable hours in large law firms is not so much related to the product as it is to providing a means of control over the work and lives of lawyers; and

$\Omega$ increasing specialisation of legal work means that almost no one sees a transaction from beginning to end; as a result, there is a separation of work being done from accountability/responsibility in terms of its goals or its overall impact.

Thornton argued that the impact of technocentrism on legal work and legal education was an "ideological desensitization". ${ }^{52}$ As Charles Derber argued, this concept suggests that legal practitioners are "absolved from ethical responsibility" when they serve dubious interests: "technocentrism permits the normalization of property and profit-making enterprises" and similar views in relation to sexism and racism..$^{53}$ Thus:

Law students need to undergo a process of ideological desensitisation in preparation for practice. Hence, issues of ethics and justice are likely to be given short shrift and to be treated as subordinate to mastery of technocratic rules. Derber reports that studies involving first-year students in a wide range of professions, including law, reveal a rapid shift from a predominantly moralorientation to a technocratic one ${ }^{\ldots 54}$

In such a context, it appears at first glance that the CBA task force completely failed to appreciate the importance of legal work and its culture in large law firms. Although Touchstones acknowledged the existence of workplace demands, it did not fully accept the priority presently accorded to work in law firm culture. Instead, 
Touchstones argued that the primary focus in the profession should be the requirements of justice, and that the achievement of gender equality goals was a matter of justice. ${ }^{55}$ Challenging the idea that lawyers must respond fully to market demands, Touchstones argued that the legal profession must take seriously its public role, aspiring to meet the traditional ideal of lawyers as "noble and learned", and refusing to succumb to the role of "high priced technicians", responding only to the needs of the corporate elite. In this way, the report reveals the validity of Hagan and Kay's conclusion that the profession in the 1990s constituted "a contested domain"; ${ }^{56}$ Touchstones' conception of the profession and its responsibility for justice directly challenged dominant ideas of the legal profession as market-driven and tending to corporatism and commodification, technocentrism and asynchronicity.

Not surprisingly in this context, as I reflected on my experiences with the gender equality seminars for major law firms, I initially concluded that the CBA recommendations were simply wrong, or at least seriously misguided, even naive. Although my criticisms may be too strong, I remain convinced that the CBA task force failed to create an imaginative strategic plan for achieving change in the legal profession in relation to its goals of gender equality. At the same time, however, it is arguable that the CBA report represents a voice about justice within the Canadian legal profession, a voice which presents both challenge and resistance to the dominant discourse of technocentrism. As my experiences with these gender equality seminars in Toronto law firms reveal, the challenge of achieving justice goals in a technocentric legal universe remains daunting: the challenge of 'fitting' gender equality goals (justice) into lawyers' work demands without requiring any changes to existing conditions of work-or any challenges to the prevailing culture oflegal workin these firms.

One concrete example illustrates the problem, and the merits of Franklin's different approach, very well. In discussions about evening work, an issue that arose 
frequently in these seminars, the problem was usually presented as a question about the need for evening work; not surprisingly, most of the time, lawyers in these major firms accepted that work during the evening was essential. In the context of our discussions, however, it became clear that both male and female lawyers who were the parents of small children in practice left the firm about 6 p.m. in order to spend time with the children; and that by about 8 or $8: 30$ p.m., both male and female lawyers returned to work. Significantly, however, male lawyers, much more frequently than their female counterparts, physically returned to the law firms; female lawyers were more likely to plug into a technological equivalent through a home computer system. Both males and females with small children frequently worked until midnight. However, it was only the male lawyers who were 'visible' at work at the firm late at night. Indeed, compounding the gender equality issue, female lawyers sometimes indicated that their resistance to returning to the office was related to the lack of safety at night in underground parking garages in downtown Toronto, the location of most of these large law firms. As a result, it was often possible to have conversations about why male lawyers, who had increased 'face' time in the firm, were thought to have worked harder than female lawyers, particularly when all of these lawyers might well have their work products completed by 8 a.m. on the following morning. Why, we pondered, was it so important for people to be physically present in the late evenings at these firms?

Such questions raise a number of interesting issues. Certainly, in the context of the law firm seminars, it was possible to identify biases based on physical presence. Indeed, I often tried to promote the idea that the issue should be whether the work is done, and not the location in which the work is done. By contrast, Ursula Franklin's message is that it is important to think about the need for community in workplaces, and the extent to which physical presence is an important part of a sense of community. What is perhaps critical here, however, is the fact that in none of the seminars were we 
able to address the question of why people have to work such long hours in legal firms! Is all of this work really necessary? And if there is a community during the hours from 8 am to $6 \mathrm{pm}$, why is the community which is involved in 'night work' (substantially male lawyers) so much more significant? To what extent does working the longest hours mean that we are more (or less?) efficient, more (or less?) capable, more (or less?) expert? If someone can do the work and go home at 6 o'clock, without working in the evenings, why does that make them 'a less effective, less accomplished lawyer'? These kinds of questions reveal a paradox in the CBA recommendations and in my gender equality seminars. On the one hand, we succeeded in revealing that current practices are not unchangeable, while on the other hand we failed to take the work requirements, and the culture of work requirements, seriously enough. We failed to ask fundamental questions about what we are doing. And why.

Such an analysis suggests that strategies for accomplishing change in the legal profession must take account of the fundamental imperatives of the work itself, and especially the culture within which legal work is done. The CBA report assumed that lawyers' responsibility to achieve justice meant that they would embrace principles of gender equality willingly once they understood them as important to accomplishing the goals of a just society. Such an assumption does not sufficiently recognise the power of workplace demands in the law firm culture: even lawyers who accept responsibility for 'justice' goals need to take seriously the competing demands of work and legal culture in creating appropriate strategies.

Thus, while the CBA report supported a reconceptualising of the profession in terms of its primary commitment to justice, it did not sufficiently confront the most fundamental barrier to change: the nature of legal work. As a result, the report failed to respond to the power of work demands to sideline other goals, including those of gender equality. In this context, educational programmes about gender equality might represent another voice in the 'contested domain' about the nature of the legal profession, but they do not constitute an effective strategy for achieving 
substantive change. Thus, it is important to acknowledge the possibility of change, without minimising the power of existing barriers to curtail and constrain it, and to understand that educational programmes about gender equality for the legal profession are not a panacea.

And this is where Ursula Franklin's lifelong work is so significant. Undoubtedly, resistant voices of justice in the legal profession are the equivalent of Franklin's earthworm theory of social change: the voices which prepare the soil for change to happen:

I have long subscribed to what I call Franklin's earthworm theory of social change. Social change will not come to us like an avalanche down the mountain. Social change will come through seeds growing in well prepared soil-and it is we, like the earthworms, who prepare the soil. We also seed thoughts and knowledge and concern. We realize there are no guarantees as to what will come up. Yetwe do know that without the seeds and the prepared soil nothing will grow at all. I am convinced that we are indeed already in a period in which this movement from below is becoming more and more articulate, but what is needed is a lot more earthworming …..57

In my view, it is altogether obvious that in the legal system, as in the social world, change will not come from the mountain top but rather from earthworming: the preparation of the soil by individuals who are prepared to challenge the mainstream. In such a context, thoughtful law teachers might choose to emulate the earthworms: Where, if not in school and workplace, is society built and changed?

\section{Acknowledgement}

The author gratefully acknowledges the technical assistance of Hazel Pollack. 
[1] U. Franklin, The Real World of Technology, revised edition (Toronto, Anansi, 1999), at 172-173 (emphasis added).

[2] Ibid., at 5 (emphasis added). Franklin explicitly connected her ideas about technology to those of C.B. Macpherson about democracy:

Technology, like democracy, includes ideas and practices; it includes myths and various models of reality. And like democracy, technology changes the social and individual relationships between us. It has forced us to examine and redefine our notions of power and of accountability (Ibid., at 2).

[3] Canadian Bar Association, Touchstones for Change: Equality, Diversity, Accountability (Ottawa, Canadian Bar Association, 1993) (hereafter Touchstones).

[4] See M.J. Mossman, Engendering the legal profession: the education strategy, in: U. Schultz \& G. Shaw (Eds) Women in the World's Legal Professions (Oxford, Hart Publishing, 2003), p. 77; and M.J. Mossman, Gender equality education and the legal profession (2000) 12 Supreme Court Law Review, 2nd series, 187.

[5] For an excellent overview, see F. Kay \& J. Brockman, Barriers to gender equality in the Canadian legal establishment (2000) 8 Feminist Legal Issues 169; reprinted in: U. Schultz \& G. Shaw (Eds), Women in the World's Legal Professions (Oxford-Portland Oregon: Hart Publishing, 2003), op. cit. For an overview of the experiences of the first women lawyers in Canada and in some other jurisdictions, see also M.J. Mossman, Portia's progress: women as lawyers, reflections on past and future (1988) 8 Windsor Yearbook of Access to Justice 252. Part of my current project involves mapping the history of the first women lawyers in different jurisdictions of the common law and civil law world in the late nineteenth and early twentieth centuries.

[6] For example, in British Columbia, only 3.2\% of members of the Law Society were women in 1971 , but they represented $21.1 \%$ of members in 1990 , while in Ontario, $83 \%$ of practising women lawyers, compared to $42 \%$ of male lawyers, had been called to the bar in the previous decade.

[7] Touchstones, at 48-50. See also Kay \& Brockman, op. cit.; and S. Boyd, E. Sheehy \& J. Bouchard (Eds), Canadian Feminist Perspectives on Law: An Annotated Bibliography of Interdisciplinary Writings (1999) 11 Canadian Journal of Women and the Law.

[8] C. Menkel-Meadow, The comparative sociology of women lawyers: the 'feminization' of the legal profession (1987) 24 Osgoode Hall Law Journal 897. Menkel-Meadow also explored these issues in R. Abel \& P. Lewis (Eds), Lawyers in Society: Comparative Theories, Vol. 3 (Berkeley, University of California Press, 1989); her research relied on reports prepared for the legal profession project in Canada, the United States, the United Kingdom, Scotland, New Zealand, Belgium, Germany, Norway, France, Italy, Spain, Yugoslavia, Brazil, Venezuela, Japan and India. The national report prepared for Canada provided only a few paragraphs, however, about gender issues: see H. Arthurs, F. Zemans \& R. Weisman, Canadian lawyers: a peculiar professionalism, in: R. Abel \& P. Lewis (Eds) Lawyers in Society: the Common Law World, Vol. 1 (Berkeley, University of California Press, 1988). For an early study of the stratification of the Ontario legal profession, see B. Adam \& K. Lahey, Professional opportunities: a survey of the Ontario legal profession (1981) 59 Canadian Bar Review 674.

[9] C. McGlynn, The Woman Lawyer: Making the Difference (London, Butterworths, 1998).

[10] Ibid., at 3.

[11] H. Sommerlad \& P. Sanderson, Gender, Choice and Commitment: Women Solicitors in England and Wales and the Struggle for Equal Status (Aldershot, Ashgate Dartmouth, 1998); and see M.J. Mossman, Review (2001) 39(4) Osgoode Hall Law Journal 870.

[12] M. Harrington, Women Lawyers: Rewriting the Rules (New York, Plume, 1995).

[13] Ibid., at 170. For earlier studies of women in law, see C. Fuchs Epstein, Women in Law, 2nd edition (Chicago, University of Illinois Press, 1993); and R. Moss Kanter, Reflections on women and the legal profession: a sociological perspective (1978) 1 Harvard Women's Law Journal 1.

[14] M. Thornton, Dissonance and Distrust: Women in the Legal Profession (Sydney, Oxford University Press, 1996), at 3-4.

[15] Ibid., at 291.

[16] Ibid., at 290.

[17] B. Lentz \& D. Laband, Sex Discrimination in the Legal Profession (Westport, CT, Quorum Books, 1995).

[18] Ibid., at xvi.

[19] Ibid., at xviii-xix. The authors' conclusion about the ineffectiveness of existing civil rights law was explored more fully, with similar conclusions, in K. Bumiller, The Civil Rights Society: The Social Construction of Victims (Baltimore, John Hopkins University Press, 1988).

[20] J. Brockman, Gender in the Legal Profession: Fitting in or Breaking the Mould (Vancouver, UBC Press, 2001). Brockman used an initial sample which included all women and men called to the bar of British Columbia between 1986 and 1990, and who were still members on 25 June 1993. 
Only those practising in government, a private law firm or industry were included. The final group included women and men with between 3 and 7 years at the bar, with equal numbers of men and women among the 100 lawyers who were interviewed individually. Brockman included information volunteered by her interviewees in relation to race, class, disability and orientation, but they were not expressly included in her sample because of the difficulty of drawing it from Law Society data. SeeIbid., at 14-17.

[21] Ibid., at 200.

[22] Ibid., at $202 \mathrm{ff.}$ See also J. Williams, Gender wars: selfless women in the Republic of Choice (1991) 66 New York University Law Review 1559; and J. Williams, Unbending Gender: Why Family and Work Conflict and What to do About It (New York, Oxford University Press, 2000).

[23] Sommerlad \& Sanderson, op. cit.

[24] Ibid., at 284-285.

[25] For example, see R.L. Nelson, D.M. Trubek \& R.L. Solomon (Eds), Lawyers' Ideals/Lawyers' Practices: Transformations in the American Legal Profession (Ithaca, Cornell University Press, 1992); J.P. Heinz, E.O. Laumann, R.L. Nelson \& E. Michelson, The changing character of lawyers' work: Chicago in 1975 and 1995 (1998) 32(4) Law and Society Review 751; G. Hanlon, Lawyers, the State and the Market: Professionalism Revisited (London, MacMillan Press Ltd, 1999); J. Flood, Megalawyering in the global order: the cultural, social and economic transformation of legal practice (1996) 3(1/2) International Journal of the Legal Profession 169; and H. Sommerlad, Managerialism and the legal profession: a new professional paradigm (1995) 2(2/3) International Journal of the Legal Profession 159.

[26] J. Hagan \& F. Kay, Gender in Practice: A Study of Lawyers' Lives (Oxford, Oxford University Press, 1995).

[27] Ibid., at 181-182.

[28] Ibid., at 12-14. Sommerlad and Sanderson also provide a sustained critique of the explanation of 'choice' in relation to differing gendered experiences in the practice of law. See Sommerlad \& Sanderson, op. cit., especially at $27 \mathrm{ff}$.

[29] Menkel-Meadow, op. cit.

[30] Hagan \& Kay, op. cit., at 187-188.

[31] Ibid., at 196.

[32] Ibid., at 198-203.

[33] Menkel-Meadow, op. cit.

[34] Such strategies may be problematic in the long term; for an analysis in the UK, see C. McGlynn, Strategies for reforming the English solicitors' profession: an analysis of the business case for sex equality, in: Schultz \& Shaw (Eds), op. cit., at 159.

[35] Hagan and Kay were also involved in research for the Touchstones report: see F. Kay \& J. Hagan, The structural dynamics of the law firm, (Appendix 13 of Touchstones). John Hagan was also a member of the CBA task force which produced the Touchstones report.

[36] At the outset, the report focused on the motivations for change in the legal profession in relation to goals of gender equality; one motivation identified was the need for "enlightened self-interest and accountability of the profession": see Touchstones, at 17-19.

[37] Touchstones, at 1.

[38] The relationship between goals of gender equality and an overall professional commitment to justice were evident, for example, in her endorsement of the views of two American authors who asked:

What is a reasonable response to the fact that large numbers of people entering law find basic incompatibility with the [lawyer's] role? One attorney suggests, "Ifyou can't stand the heat, get out of the kitchen." A more thoughtful reply would be to ask: What is wrong with the kitchen that so many bright, competent people find it difficult to work there? What happens if people work all day in a kitchen that is too hot?... What [can] we learn about the legal system and about the possible changes which need to be made?

See Touchstones, at 268; quoting D. Jack \& R. Jack, Women lawyers: archetypes and alternatives, 
in: Gilligan, Ward \& Taylor (Eds) Mapping the Moral Domain (Boston, Harvard University Press, 1988).

[39] In spite of the dramatic rate of increase for women members of the legal profession, the CBA's 1993 report concluded that there had been all too little change in the legal profession in relation to the reception of women lawyers:

The dimensions of the problems experienced by women in the legal profession are staggering. In a country where gender equality is entrenched as a primary constitutional value, and in a self-governing profession knowledgeable about law and concerned with justice, women continue to be discriminated against in numerous overt and covert ways (Touchstones, at 10).

[40] Although a number of provincial law societies sponsored similar studies during the same period, the national scope of the CBA study and its process of consultation over several years made it a primary focus of discussion for both the legal profession and the public on issues about gender equality in Canadian law. For other examples, see Law Society of British Columbia, Women in the Legal Profession: A Report of the Women in the Legal Profession Subcommittee (1991); Law Society of British Columbia, Gender Equality in the Justice System: A Report of the Law Society of British Columbia Gender Bias Committee (1992); and F. Kay, Transitions in the Ontario Legal Profession: A Survey of Lawyers Called to the Bar Between 1975-1990 (A report to the Law Society of Upper Canada, Osgoode Hall, Toronto, 1991). A number of provincial reports were also prepared as part of the research for the Touchstones report.

[41] Only in the last chapter of the report was there a concerted effort to assess the problems and possibilities of achieving fundamental institutional change. In chapter fifteen, the report identified the reform challenge as "momentous", and recognised a need for both individual and institutional change to achieve gender equality objectives for lawyers. Moreover, the report recognised that change might not occur all at once, advocating that "incremental change [was] possible and necessary". Just as significantly, Touchstones identified some of the points of resistance to proposed changes to achieve gender equality goals, including the "myth" that progress is being made already; the harsh economic climate; issues of reverse discrimination; complacency and "a consensus of denial"; ideas about the proper role for women; and problems of backlash that silence legitimate complaints. Touchstones, at 267-271.

[42] Touchstones, at 271.

[43] Touchstones, at 271. For another assessment of the problems of the status quo for law and lawyers, see M.J. Mossman, Gender equality and the Canadian Charter: making rights work for women? In: P.Smith (Ed.) Making RightsWork(Dartmouth, Ashgate, 1999).

[44] Touchstones, at 271-272.

[45] For analysis, see M.J. Mossman, Gender issues in teaching methods: reflections on shifting the paradigm (1995) 6(2) Legal Education Review 129; and M.J. Mossman, Justice, technology and the struggle for hope (2002) 51 UNB Law Journal 49.

[46] The seminars were provided on a confidential basis; thus, no information identifying the firms is available.

[47] After a period of consultation, I designed a programme which could be presented to 15-20 lawyers in an interactive seminar format, using both video problems and written problems on three aspects of gender equality: issues about work assignment, performance assessment and promotion criteria and procedures; issues about the work environment, including problems of sexual harassment as well as issues about collegiality and client development; and issues about the relationship between work and family responsibilities. The seminar programme devoted about one-third of its time to discussion of each of these three groups of issues. For each group of issues, there was a short introduction, often providing an overview of legal principles (using an overhead projector), and an opportunity for questions or initial comments from participants. Each segment then turned to a short video presentation of some aspects of the problem, and participants were asked to consider how to define the problems and the options for solution along with their probable costs and consequences. In addition to the video problems, each segment also included analysis and discussion of additional problems which demonstrated related, but somewhat different, aspects of 
the issues illustrated in the video problems. At the end of all three segments, there was frequently time for only a brief conclusion, and participants were referred to written materials which were available for them to take away from the seminar for further reference. The video segments used in the programme were parts of two videos produced in the United States: one was Further Adventures in Legal Ethics (Professor S. Gillers, NYU Law School); and the other was All in a Day's Work (Ginzberg Video Productions, CA). For an analysis of the pedagogical challenges presented by these seminars, see Mossman (2003), op. cit.

[48] Thornton, op. cit., at 149-151.

[49] M. Cain \& C. Harrington (Eds), Lawyers in a Postmodern World: Translation and Transgression (New York, New York University Press, 1994), at 2.

[50] Thornton, op. cit.

[51] Franklin, op. cit., at 151 (emphasis added).

[52] See Thornton, op. cit., at $75 \mathrm{ff}$. Thornton acknowledged the work of Charles Derber, Professionals as Workers: Mental Labour in Advanced Capitalism (Boston, GK Hall \& Co, 1982).

[53] Thornton, op. cit., at 76-77.

[54] Ibid., at 76-77.

[55] For example, the report stated:

The demands for gender fairness and equality are not the claims of a special interest group. They are legal and ethical issues of fairness and justice for the profession as a whole. They are not 'women's issues' but evidence of a serious flaw in the structure and organization of the profession (Touchstones, at 17).

[56] Hagan and Kay, op. cit., at 179.

[57] Franklin, op. cit., at 121-122. 